\title{
Business Strategy Formulation for Training Company in Captive Market
}

\author{
Denada Tirta Amertha, Alla Asmara, and Setiadi Djohar
}

\section{ABSTRACT}

This study aims to formulate a business strategy at a training company (PT PTC) as a lead training provider in facing competition in the Pertamina Group market (captive) and in the non-captive market. The internal business environment was identified using VRIO analysis and evaluated using the IFE Matrix, while the external business environment was identified using Porter's Five Forces and evaluated using the EFE Matrix. The formulation of alternative business strategies in the PTC training business unit is carried out using the SWOT Matrix which is then outlined in the business strategy implementation roadmap. The results showed that PT PTC's training business unit was in a position to grow and develop with good internal capabilities in using strengths and minimizing weaknesses (score 2,570 ), and in a strong position to respond to opportunities and threats (score 3,042). The results of the VRIO analysis obtained 4 future competencies for strategy formulation on the SWOT Matrix and obtained 9 alternative intensive strategies in the form of market penetration strategies, market, and product development as well as 1 horizontal integration strategy, then ranked using QSPM for a roadmap of PTC training business strategy implementation in 5 years front.

Keywords: Business Strategy, Business Training, Non-Formal Education, Strategy Formulation.

\section{INTRODUCTION}

The service sector is classified by the World Trade Organization (WTO) into 12 sections, one of which is education services. Education services in the KBLI (Baku Classification of Indonesian Business Fields) are classified into two parts, namely: formal education and non-formal education. According to Suryono and Tohani [1], non-formal education services have a role in shaping people as an economic driving instrument in various industries, one of which is the oil and gas industry which has great significance for Indonesia's economic growth.

The complexity of PT Pertamina (Persero)'s business processes from upstream to downstream requires the Company to build a strong business network spread throughout Indonesia as an effort to provide optimal services to the community. This is done by establishing subsidiaries that have strategic roles in the upstream, downstream, and supporting sectors (finance and services). In the period 2010 2018, the number of subsidiaries of PT Pertamina (Persero) has increased every year [2]. In 2019 there was an acquisition of subsidiaries so that the number of subsidiaries experienced a reduction, but in terms of the number of employees there was an increase with a positive trend.

The increasing trend of the growth in the number of Pertamina Group employees has become a separate homework for PT Pertamina (Persero) to ensure that existing human resources can contribute positively to the achievement
Submitted : July 01, 2021

Published : July 23, 2021

ISSN: $2507-1076$

DOI: $10.24018 /$ ejbmr.2021.6.4.965

Denada Tirta Amertha*

Sekolah Bisnis - IPB University, Bogor, Jawa Barat, Indonesia.

(e-mail: surat.nada@ gmail.com)

Alla Asmara

Department of Economics, Faculty of

Economics and Management, IPB

University Bogor, Jawa Barat, Indonesia.

Setiadi Djohar

Sekolah Tinggi Manajemen Ppm, Jakarta Pusat, DKI Jakarta, Indonesia

*Corresponding Author of the Company's targets, then PT PTC is formed as a subsidiary that plays a role in the supporting sector (finance and services) in supporting development of human resource competencies through non-formal education services, this is in line with the results of research conducted by Alamzah and Simanjuntak [3] that human resource management strategy plans through business partner model strategies can increase employee productivity. The training services offered by PTC are divided into 2 (two) forms of training, namely: in-house training and public training with types of training, namely: Oil and Gas technical training (Oil and Gas), managerial training, and leadership training.

The growth of training revenue obtained from the captive market and from the non-captive market is relatively slow. In a study conducted by Pradnyani et al. [4] resulted that profitability is significantly influenced by revenue growth and capital structure. In 2019, the proportion of PT PTC's training revenue was dominated by the Pertamina Group (captive) market of $94.98 \%$, with PT Pertamina (Persero) as the parent company as domination of $83.20 \%$, and the remaining $16.80 \%$ filled by sectors other business sectors, namely: the upstream sector by $7.20 \%$, the downstream sector by $8.00 \%$, and the supporting sector (financial \& services) by $1.60 \%$ while $5.02 \%$ came from outside markets. Pertamina Group market (non-captive).

In fact, the increase in the number of Pertamina Group employees is not directly proportional to the increase in revenue training received by PT PTC. Based on the 
consolidated financial statements of the Pertamina Group from 2010 to 2019, the absorption of Pertamina Group's training budget has a positive trend with a growth rate of $7.72 \%$ [5], but it is not directly proportional to the growth of PT PTC's training revenue of $6.19 \%$, the average ability of the business unit training for PT PTC to gain market share in the Pertamina Group of $8.90 \%$ of the total realization of the Pertamina Group's annual training budget absorption. In the non-captive market, the competition is getting tougher with the presence of technology-based training providers and a shift in customer trends, especially during this pandemic to online learning. The overlapping of internal training providers in the Pertamina Group as well as the presence of digital startups and other external training providers that play in the managerial training and leadership training segments in the Pertamina Group market have an impact on the slow growth of PT PTC's training business. Due to the overlapping of training providers in the internal group, PT Pertamina (Persero) as the parent company in 2019 issued a policy for structuring the business scope of its subsidiaries and appointed PT PTC as the lead training provider in the Pertamina Group market.

After being appointed as the lead training provider in the Pertamina Group market in 2019, revenue growth was still slow at $2.98 \%$, especially gross profit growth was relatively small at $0.59 \%$ in the same period. The implementation of business synergy has not been able to provide significant leverage on the financial side of the business. Based on the performance data, the Board of Directors of PT PTC considers that efforts need to be made to maximize the opportunities that have been provided as lead training providers so that there is an increase in the absorption of training budgets in the internal group by the training business unit of PT PTC, able to compete in non-captive markets, and contribute more to the parent company in the form of added value for human resource development and increased profits.

\section{LITERATURE REVIEW}

\section{A. Strategic Management}

Strategy in general can be interpreted as a tool to achieve a goal. Strategic planning can help companies to see internal and external conditions more objectively so that companies can respond appropriately to changes in the business environment, this is in line with Rangkuti [6] who says that strategy is a very important tool to achieve competitive advantage. In line with this thought, Harisudin [7] said that strategy is a tool to achieve goals, so the terminology of strategic management must have three characters at once, namely: unified, comprehensive, and integral.

\section{B. Planning and Strategic Design}

Wheelen and Hunger [8] divide strategy into three groups of parts known as the hierarchy of strategies, the three groups, namely:

1) Corporate strategy, Rangkuti [6] explains that corporate strategy is a strategy formulated in a business, when a company will compete by changing its distinctive competence (competencies that are not easily imitated by competitors into competitive advantages.

2) Business strategy, The Strategic Business Unit (SBU) described its characteristics by Rangkuti [6], including having a mission and strategy, producing products or services related to missions and strategies, producing specific products or services, and competing with well-known competitors.

3) Function strategy, Functional strategies are operational in nature because they are directly related to management functions such as production/operational management functions, marketing functions, financial functions, and human resources functions.

The basic elements of strategic management according to Wheelen and Hunger [8] are divided into four parts, namely:

1) Environmental scanning is an activity to monitor, evaluate, and seek information from the external and internal environment for important people in the company. The aim is to identify the external and internal strategic factors that will determine the future of the company.

2) Strategy formulation is the development of a long-term plan to respond to opportunities and threats to the business environment based on the company's strengths and weaknesses. Strategy formulation includes determining the company's mission, determining achievable goals, developing strategies, and establishing policy guidelines.

3) Strategy implementation, the process of implementing strategies and policies that are packaged in a series of actions through the development of programs, budgets, and procedures. This process can be through changes in the culture, structure, or managerial systems of the entire organization.

4) Evaluation and control, this process serves to evaluate and provide oversight of the strategic plan that is carried out and in this process the weaknesses of the strategic plan that are implemented can be identified and encourage the whole process to restart.

David [9] formulates a framework for formulating a strategy which consists of three stages, namely:

Stage 1: Input Stage

\begin{tabular}{ccccc} 
EFE Matrix & $\begin{array}{c}\text { Competitive } \\
\text { Profile Matrix }\end{array}$ & IFE Matrix \\
\hline \multicolumn{4}{c}{ Stage 2: Matching Stage } \\
SWOT & SPACE & BCG & I/E & $\begin{array}{c}\text { Grand Strategy } \\
\text { Matrix }\end{array}$ \\
Matrix & Matrix & Matrix & Matrix & \\
\hline \multicolumn{4}{c}{ Stage 3: Decision Stage } \\
& \multicolumn{4}{c}{ QSPM }
\end{tabular}

Fig. 1. Strategic Formulation Analytical Framework.

\section{RESEARCH METHODOLOGY}

Wheelen and Hunger [8] divide strategy into three groups of parts called the strategic hierarchy, namely: corporate strategy, business strategy, and function strategy. The research approach used in preparing business strategies is descriptive in the form of case studies on PTC's training business. The research was conducted at the PTC Head Office and the location selection was purposive with the consideration that PT PTC is a Pertamina subsidiary that has been appointed as the lead training provider in the Pertamina 
Group. The research method uses descriptive qualitative and quantitative descriptive methods. Qualitative descriptive method was conducted through interviews to identify key internal factors, external key factors and stakeholder expectations with research instruments, namely questionnaires and literature studies. Quantitative descriptive method with weighting and assessment of the results of filling out the questionnaire.

The data collection method used to obtain primary data is through stakeholder interviews involved in the preparation of training business strategies at PT PTC, while secondary data is in the form of literature studies including company internal documents and other relevant literature sources. Budiman et al. [10] in his research used in-depth interviews to identify internal and external factors used in the preparation of digital banking development strategies. Determination of respondents is done intentionally (purposive sampling) based on the organizational structure of the companies involved in preparing the training business strategy at PTC, namely: Director of Operations \& Marketing, Director of Finance, Strategic Plan Manager, Training \& Consulting Manager, Assistant Business Training Manager, Associate Trainer and external parties, namely: Pertamina's Subsidiary and Joint Venture functions and PT PTC's training business customers from various sectors. The operational framework is structured to make it easier to understand the outline of the logical flow of this research, which can be seen in Fig. 2.

The data processing and analysis method uses a three-stage analysis approach to strategy formulation from David [9], namely: input stage, matching stage, and decision stage to answer the objectives of this study. The input stage is carried out by evaluating internal and external environmental factors by:

1) Identifying and analyzing internal factors using VRIO analysis, Rumau [11] uses paired comparison in his research to make comparisons between the results of an employee's performance that will be assessed with the results of the performance of other colleagues so that appraisers can assess effectively. Wandrial [12] in his research uses the VRIO framework to determine basic criteria so as to produce identification of internal resources with a competitive advantage.

2) Identifying and analyzing external factors using Porter's five force analysis with the aim of identifying external factors that are opportunities or threats, Manurung et al. [13] in his research using an analysis of five competitive forces to win the competition in the non-formal education service business and resulted in the identification of opportunities and threats to the Smart Learning Center business.

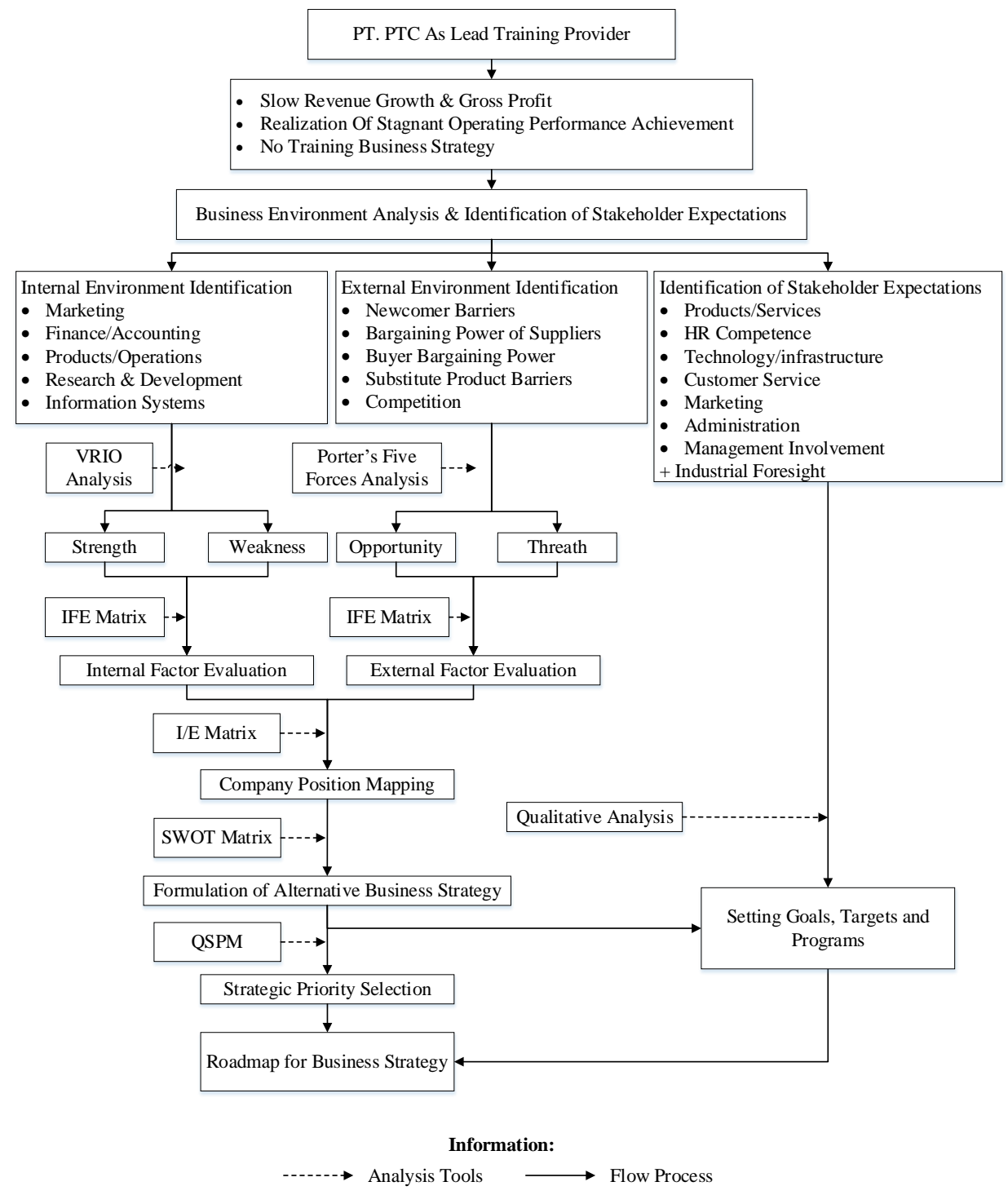

Fig. 2. Magnetization as a function of applied field. 
3) Identifying stakeholder expectations using a questionnaire as done by Guswandi et al. [14] in his research involving various stakeholders to provide an overview of the state of the industry in the future so that a business strategy is produced that is in accordance with the needs and challenges of future business. Furthermore, a rating is carried out on each internal and external factor obtained and the weighting of each factor using the paired comparison method, then entering the weights and ratings into the IFE matrix and the EFE matrix. Firmiyanti et al. [15] in his research conducted a quantitative evaluation using the EFE matrix and the IFE matrix to obtain positioning.

The matching stage to formulate alternative business strategies is carried out in two stages, namely:

1) Entering the identified key factors into the IE Matrix to determine the positioning of PTC's training business.

2) Formulating a training business strategy based on the company's position in the IE Matrix using the SWOT Matrix. Wongwa [16] formulated a strategy using the SWOT Matrix for business planning for entrepreneurial education training services through internal environmental analysis so as to produce a synergy strategy with educational institutions to overcome the threat of competition in the future as well as strategies for product differentiation and facilities offered. Saragih and Suwardi [17] using SWOT analysis to generate competitive strategies in the form of maximizing the use of technology and improving services. Sukaatmadja et al [18] in their research used the SWOT Matrix so that the traditional market business position was in Cell I in the IE Matrix which was developed into an alternative strategy in the SWOT Matrix. Wiagustini [19] in his research to formulate a strategy for developing Small and Medium Industries for Herbal Products using the SWOT Matrix, he obtained an intensive strategy and an integrative strategy.

The decision stage is the final stage of the analytic framework of strategy formulation. At this stage, a strategy rating is carried out to obtain a priority list referring to the six stages of QSPM development described by David [9]. Mahfud and Mulyani [20] in their research used the QSPM to determine the priority of alternative strategies and resulted in a priority sequence of strategies for improving the quality of study program graduates. Hidayati [21] carried out a priority strategy decision-making process using the QSPM by calculating its relative attractiveness to various internal and external factors in order to obtain a strategic priority order. The preparation of the PT PTC training business strategy roadmap is carried out by combining the results of the preparation of objectives based on the vision, mission and expectations of stakeholders, targets and programs based on the Company's Long Term Plan as well as stakeholder aspirations and the results of strategic priorities in the QSPM.

\section{RESEARCH RESUlt AND DISCUSSION}

\section{A. Identification of Internal Environmental Factors}

Identification of the internal training business environment using a VRIO analysis approach (Value, Rarity, Immitability, Organization) based on internal aspects by David [9]. Identification of internal environmental factors is carried out through interviews with 6 (six) internal respondents with the aim of identifying the strengths and weaknesses of the training business. Based on the results of the identification of the internal environment, the implications of competitive, economic performance and the weaknesses or strengths of each factor are obtained. Furthermore, a rating process is carried out by internal respondents based on the results obtained to determine each of the 5 (five) internal environmental factors that are considered the most important and most influential. The variables of these internal factors are strengths and weaknesses in Table I.

\begin{tabular}{|c|c|c|c|c|}
\hline \multicolumn{2}{|r|}{ Internal Factors } & Weight & Rating & Score \\
\hline \multicolumn{5}{|c|}{ Strengths } \\
\hline 1 & $\begin{array}{l}\text { Have the ability to sell products / } \\
\text { services through face-to-face sales } \\
\text { and build relationships with } \\
\text { customers }\end{array}$ & 0,096 & 3,000 & 0,289 \\
\hline 2 & $\begin{array}{l}\text { Have a strong business brand (the } \\
\text { brand is attached to the competence } \\
\text { of Pertamina's frontliners who are } \\
\text { directly involved with community } \\
\text { activities) }\end{array}$ & 0,107 & 3,000 & 0,322 \\
\hline 3 & $\begin{array}{l}\text { Ease of access to utilize training } \\
\text { production resources (experts and } \\
\text { location of training facilities) owned } \\
\text { by Pertamina Group and scattered } \\
\text { throughout Indonesia }\end{array}$ & 0,104 & 4,000 & 0,415 \\
\hline 4 & $\begin{array}{l}\text { Have the ability to deliver training } \\
\text { services for Pertamina Group } \\
\text { frontline workers in frontier and } \\
\text { remote areas }\end{array}$ & 0,122 & 4,000 & 0,489 \\
\hline 5 & $\begin{array}{l}\text { Have the ability to develop new } \\
\text { products / services according to } \\
\text { current market demands }\end{array}$ & 0,102 & 4,000 & 0,407 \\
\hline \multicolumn{5}{|c|}{ Weaknesses } \\
\hline 1 & $\begin{array}{l}\text { Business planning related to } \\
\text { preparation for the future has not } \\
\text { been prepared in the form of a } \\
\text { formal document }\end{array}$ & 0,119 & 1,000 & 0,119 \\
\hline 2 & $\begin{array}{l}\text { There is no standard pricelist to gain } \\
\text { control over the price charged to } \\
\text { consumers }\end{array}$ & 0,095 & 1,000 & 0,095 \\
\hline 3 & $\begin{array}{l}\text { The methods for analyzing the costs } \\
\text { / benefits of market job } \\
\text { opportunities are unclear }\end{array}$ & 0,088 & 2,000 & 0,176 \\
\hline 4 & $\begin{array}{l}\text { Weak ability to manage COGS / } \\
\text { Production Cost growth }\end{array}$ & 0,092 & 2,000 & 0,183 \\
\hline \multirow[t]{2}{*}{5} & $\begin{array}{l}\text { There has not been any monitoring } \\
\text { of product / service trends to project } \\
\text { growth / shift in customer needs }\end{array}$ & 0,075 & 1,000 & 0,075 \\
\hline & Total & 1,000 & & 2,570 \\
\hline
\end{tabular}

\section{B. Identification of External Environmental Factors}

Identification of the external environment of the training business using Porter's Five Forces analysis approach through interviews with 6 (six) internal respondents with the aim of identifying opportunities and threats factors. Prasasti [22] conducted an analysis of Porter's Five Forces and resulted in the company's position in the industrial environment to survive the threat of competition or dominate the competition. Wibawa et al. [23] conducted an industry analysis using Porter's Five Forces analysis and generated categories of threats and opportunities in the online ride-sharing industry. Based on the results of the identification of the external environment, a rating process is then carried out to determine each of the 5 (five) external environmental factors (opportunities and threats) which are considered the most important and most influential, as illustrated in Table II. 
TABLE II: External Factor Evaluation (EFE Matrix)

\begin{tabular}{|c|c|c|c|c|}
\hline & External Factors & Weight & Rating & Score \\
\hline \multicolumn{5}{|c|}{ Opportunities } \\
\hline 1 & $\begin{array}{l}\text { There is no relationship between } \\
\text { customers and customers in terms } \\
\text { of image, sharing capabilities, } \\
\text { marketing, shared facilities, etc. }\end{array}$ & 0,115 & 3,000 & 0,344 \\
\hline 2 & $\begin{array}{l}\text { Companies can make use of } \\
\text { available training resources to } \\
\text { meet market needs (Captive \& } \\
\text { Non Captive) }\end{array}$ & 0,104 & 4,000 & 0,415 \\
\hline 3 & $\begin{array}{l}\text { High interest of suppliers / third } \\
\text { parties who wish to partnership } \\
\text { with PTC business training }\end{array}$ & 0,111 & 3,000 & 0,333 \\
\hline 4 & $\begin{array}{l}\text { The difficulty of challenging to } \\
\text { influence consumers to shift / } \\
\text { switch to other products }\end{array}$ & 0,105 & 4,000 & 0,419 \\
\hline 5 & $\begin{array}{l}\text { Competitors find it difficult to } \\
\text { access the captive market to apply } \\
\text { their products }\end{array}$ & 0,095 & 4,000 & 0,381 \\
\hline \multicolumn{5}{|c|}{ Threats } \\
\hline 1 & $\begin{array}{l}\text { The technological capabilities that } \\
\text { are owned / used in the training } \\
\text { business are common things that } \\
\text { are shared by competitors }\end{array}$ & 0,117 & 3,000 & 0,350 \\
\hline 2 & $\begin{array}{l}\text { There has been competition for } \\
\text { the Pertamina Group market by } \\
\text { competitors for expansion due to } \\
\text { the slow growth of the non-formal } \\
\text { education service industry in other } \\
\text { markets }\end{array}$ & 0,092 & 3,000 & 0,275 \\
\hline 3 & $\begin{array}{l}\text { If demand increases significantly, } \\
\text { business costs will also increase } \\
\text { significantly (Fixed Gross Profit } \\
\text { Margin). }\end{array}$ & 0,088 & 2,000 & 0,176 \\
\hline 4 & $\begin{array}{l}\text { Customers are concentrated in the } \\
\text { same market }\end{array}$ & 0,097 & 2,000 & 0,194 \\
\hline \multirow[t]{2}{*}{5} & $\begin{array}{l}\text { Customers have the power to bid } \\
\text { on prices by comparing similar } \\
\text { products in the market }\end{array}$ & 0,077 & 2,000 & 0,154 \\
\hline & Total & 1,000 & & 3,042 \\
\hline
\end{tabular}

\section{Positioning Business Training PT PTC}

The IE matrix is a mapping of the IFE and EFE matrix scores that have been generated from the input stage, the IFE score obtained is 2.570 (Table I) and the EFE score is 3.042 (Table II).

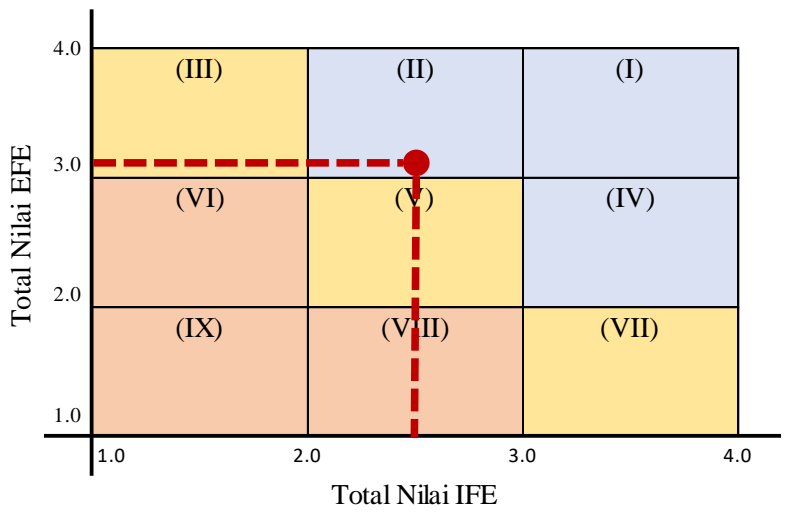

Fig. 3. Matrix of Internal / External Business Training PT PTC.

The results of combining EFE and IFE scores on the IE matrix are in cell II - Grow and Build. David [9] explains that cell II is the position of the company to grow and develop through an intensive strategy (market penetration, market development, and product development) or integrative (backward, forward, and horizontal integration).

\section{Future Competencies}

Building competitive business in future competition, it is necessary to know the current core competencies that can be developed to shape future competencies. Budiman et al. [10] compile future competencies with VRIO analysis by identifying the implications of temporary and sustainable competitive advantage. Based on the results of the VRIO analysis, it was obtained 15 core competencies with temporary competitive implications and including the strength of special competencies as well as long-term special competencies, then developed to form the future competencies of the PTC training business, and obtained 4 future competencies of the PT PTC is:

1) optimization of training management,

2) digitization of training products and services,

3) optimization of Pertamina group synergies, and

4) digital data analytics.

\section{E. PT PTC Business Training SWOT Analysis}

The result of strategy formulation using SWOT Matrix obtained SO strategy, ST strategy, WO strategy and WT strategy with a total of 10 alternative strategies. The suitability of the alternative strategies produced through the SWOT Matrix with the PTC training business position in the IE Matrix (cell II - grow and build), then the mapping of alternative strategies that can be done is intensive strategy (market penetration, market development, and product development) and integrative strategy. (horizontal integration). Ruslim and Indriyani [24] in their research explained that to improve the company's competitive position through existing products, intensive efforts are needed through intensive strategies.

\section{F. Priority Business Strategy Training PT PTC}

The determination of strategic priorities is done using QSPM by listing the strengths, weaknesses, opportunities, and threats as well as the weight values that have been generated in the IFE and EFE matrices, then each alternative strategy is given an Attractiveness Score (AS). Total Attractiveness Score (TAS) is sorted based on the highest to lowest values to see priority strategies that can be implemented in the PTC training business, the sequence of strategies is as follows:

1. Increasing the capability of the production process of training products and services in collaboration with third parties who have the best abilities in the field of nonformal education and digitizing training products and services (Weakness-Opportunities), TAS: 5,570;

2. Adjusting business performance targets and cascading into individual performance for marketing optimization and management of training to non-captive markets as well as maintaining in the captive market (StrengthThreat), TAS: 5,334;

3. Developing technical, managerial and leadership training products and services that can be marketed to non-captive markets by utilizing synergies in internal groups and third party cooperation (Strength-Threat), TAS: 5.014;

4. Upgrading learning methods on the learning platform that is owned from learner-led elearning to facilitated learning (Strength-Threat), TAS: 4,244;

5. Strengthening the role of lead training providers in internal groups through joint operations between PTC training and training providers in the parent entity (Weaknesses-Opportunity), TAS: 4,186;

6. Establishing standard pricing for training products and services that are updated regularly by taking into account the efficiency of production costs and control over third 
parties (institutions, companies or universities) (Weaknesses-Threat), TAS: 3,794;

7. To synergize the sales of training products and services with training providers in the Internal Group for the captive and non-captive markets (Strength-Opportunity), TAS: 3,218 ;

8. Prepare a marketing program (customer loyalty program) for customer retention in the captive market (StrengthOpportunity), TAS: 3,039;

9. Developing digital analytical data for monitoring business trends and analyzing competitors (Weaknesses-Threat), TAS: 2,947;

10. Develop procedures and tools for rapid cost and benefit analysis of job training (Weaknesses-Threat), TAS: 2,657 .

\section{G. Roadmap Strategy Implementation}

Organizations that have not been able to identify competitive advantages and have great strength in producing positive financial performance will find it difficult to maintain business continuity. The road map for the implementation of the PTC training business strategy for the next 5 years is prepared based on the core competencies held to achieve the goals. The objectives are derived based on the vision, mission and expectations of stakeholders which are then linked to the future competencies of the PTC training business in building an intensive strategy and a sustainable integrated strategy. The targets used refer to the Company's Long-Term Plan and the aspirations of stakeholders, to achieve these targets the strategies used are 10 alternative strategies resulting from the SWOT analysis which are grouped based on intensive and integrative strategies. PTC work programs and business training action plans based on future competencies that will be implemented in the next 5 years:

\section{Optimization of Training Management}

PTC Training can collaborate with Professional Certification Bodies outside of Oil and Gas, especially with LSPs in the managerial field as Competency Test Sites for certification preparation training, so that training production can be more massive and become a door for expanding the non-captive market. In addition, PTC training can collaborate with edutech startups engaged in non-formal education and other edutech startups to improve their online-based learning platform management capabilities.

Adjustment of business performance targets in the performance management system is important to accelerate growth in operating performance as expected by focusing on increasing the quantity of training participants and the quantity of B2B cooperation with non-captive customers. The target of training management optimization is to increase the number of strategic partnerships with potential partners in increasing the training operation capability of 2 partnerships each year. In addition, other targets for optimization of training management are carried out by increasing the management of the number of training participants from the captive market by $6 \%$ per year according to the growth rate in 2019 and increasing the management of the number of projects (B2B) with customers in the non-captive market at least 2 projects each year.

\section{Digitizing Product and Services Training}

The use of online-based learning platforms is a trend, especially in the business world, because digitalization has become an integral part of future business activities. Users benefit because the training costs incurred can be streamlined, but all workers can get training, besides that workers can access the learning platform independently. Therefore, PTC training needs to develop digital-based training products that can be accessed through a learning platform and make adjustments to the learning methods used from learner-led elearning which only presents learning materials to become facilitated e-learning combining available independent learning materials with communication, interactive discussion forums, video conferencing and chat rooms that can be accessed simultaneously. Adjustments made to training products and learning platforms must also be supported by digital-based training services, where all endto-end services from registration to evaluation are carried out online so that the digitization of training products and services through the learning platform can go hand in hand.

The goal of digitizing training products and services is an increase in the number of training products in digital form on the learning platform, with a minimum increase of 10 products a year. Furthermore, the adjustment of online-based end-to-end services on the learning platform is part of a comprehensive digitalization that has been completed in one year. Finally, the adjustment of the learning method on the learning platform from learner-led e-learning to facilitated elearning, the adjustment is completed within one year.

\section{Optimizing the Pertamina Group Synergy}

Hari and Rachmawati [25] in their research explain that corporate synergy can work together more efficiently and more effectively by allocating long-term resources more appropriately, synergies can be created through economies of scale, economies of scope and market power. This appointment needs to be responded positively by PTC training to maximize opportunities by synergizing training providers in the parent company with support from the parent company so that the implementation of training in the internal group is well managed, one of which is through the KSO (Joint Operation) training program in the captive market. Jane [26] in her research produced a partnership, the company will get several important benefits such as access to markets, technology and capital and the company will get opportunities for innovation, knowledge creation and increase organizational capabilities and resources.

It is necessary to set a standard training price for customers from internal groups as an effort to keep the training budget owned by Pertamina Group being reabsorbed in the internal group. Apart from the operational side, synergies should also be carried out from the marketing side by integrating digital marketing channels owned by internal training providers to widen the size of the market in captive and non-captive markets. Furthermore, as an effort to manage customers (customer retention), it is necessary to develop a customer loyalty program to ensure that customers are loyal (true fans) not due to transactional relations, so it is necessary to see the willingness of customers to promote PTC training products and services and ensure that customers are easy to get training products and services. PT PTC.

The target of optimizing the Pertamina Group synergy is to increase the number of cooperative operations with training providers in the parent entity with a minimum addition of 3 cooperation programs each year. Furthermore, with the synergy in the Pertamina Group, it was able to increase training income with an average growth rate 
(CAGR) of $13.63 \%$ annually. Digital marketing collaboration will increase traffic on the available marketing channels and a minimum of $10 \%$ sales conversion occurs every year. Finally, as an effort to manage customers retention through customer loyalty programs, customers are willing to promote PTC training products and services by $60 \%$ in 2025 .

\section{Digital Data Analytics}

PTC has an integrated system for data management and work information, however the use of the existing integrated system is only limited to recording and storing data. The development of digital data analytical features in an integrated system needs to be done to determine trends in training needs, mapping potential markets in increasing sales, analyzing competitors and improving customer experience for training services. In line with the results of research conducted by Maryanto [27] that the use of big data in the business sector can find out customer responses to products issued through sentiment analysis, help make decisions appropriately and accurately, improve corporate image, business planning and find out market trends and consumer desires. . In addition, in the marketing and sales process, a procedure is required to analyze the training jobs that will be received, which can provide benefits, the rapid cost and benefit analysis tools. The goal of digital data analytics is to improve business training processes by digitizing it that can be used in early 2024 and the absence of zero loss events every year to maximize profits.

\section{CONCLUSION}

Based on the results of the analysis and discussion carried out to answer the research objectives, conclusions were obtained:

1) the PTC training business is in a growth and development position (quadrant II in the IE Matrix) with good enough internal capability or in an average position (moderate) in using strengths and minimizing weaknesses with a score of 2.570 (IFE Matrix), while responding to opportunities and threats is known to have a strong position with a score of 3.042 (EFE Matrix), strategies that can be done are intensive and integrative strategies.

2) The results of the VRIO analysis resulted in 4 future competencies: optimization of training management, digitization of training products and services, optimization of Pertamina group synergies, and digital analytical data in strategy formulation using the SWOT Matrix obtained 10 alternative intensive and continuous integrative strategies.

3) The QSPM results obtained strategic priorities for the preparation of a roadmap for the implementation of a training business strategy in the next 5 years.

\section{REFERENCES}

[1] Suryono, Y., \& Tohani, E. (2016). Non-formal Education Innovation (P. G. Cendikia (ed.); 1st ed.). Cendikia, Penerbit Graha http://staffnew.uny.ac.id/upload/130799881/pendidikan/ Inovasi Pendidikan Nonformal.pdf.

[2] Pertamina. (2019a). Annual Report. In PT Pertamina (Persero). https://pertamina.com/id/dokumen/laporan-tahunan.

[3] Alamzah, E., \& Simanjutak, A. (2013). Management and Development of Human Resources at PT. Aneka Sejahtera Engineering. Jurnal Manajemen Bisnis Petra, 1(2), 1-12.

[4] Pradnyani, I. G. A. A., Purbawangsa, I. B. A., \& Sri, L. G. (2017). The Role of Profitability in Mediating the Effect of Company Growth and Capital Structure on CSR. Jurnal Ekonomi Dan Bisnis Universitas Udayana, 6(5), 1967-1994.
[5] Pertamina. (2019b). Consolidated Financial Statements. In $P T$ Pertamina (Persero). https://www.pertamina.com /id/dokumen/laporan-tahunan.

[6] Rangkuti, Freddy. (2013). SWOT Analysis: Techniques for Dissecting Business Cases. Jakarta (ID): Gramedia Pustaka Utama.

[7] Harisudin, M. (2011). Competitive Profile Matrix as a Product or Service Marketing Strategy Analysis Tool. Jurnal SEPA: Sosial EKonomi Pertanian Dan Agribisnis, 7(2), 1-6.

[8] Wheelen, T. L., \& Hunger, J. D. (2010). Strategic Management and Business Policy: Achieving Sustainability (P. Hall (ed.); 12th ed.). Prentice Hall.

[9] David, F. R. (2011). Strategic Management Concepts and Cases (Pearson Education Inc-Prentice Hall (ed.); 13th ed.). Pearson Education Inc-Prentice Hall. http://www.mim.ac.mw/books/David's Strategic Management Concepts and Cases 13e .pdf.

[10] Budiman, H., Seminar, K. B., \& Saptono, I. T. (2020). Digital Banking Development Strategy Formulation (ABC Bank Case Study). Jurnal Aplikasi Bisnis Dan Manajemen. https://doi.org/10.17358/jabm.6.3.489.

[11] Rumau, R., Kusrini, \& Lutfi, E. T. (2015). Employee Performance Assessment Using Paired Comparison Method And Fuzzy C-Means Algorithm. Seminar Nasional Informatika, 1(1), 408-414.

[12] Wandrial, S. (2011). Company Internal Analysis (Strength \& Weakness), Using the 'Resource-Based View of the Firm' concept with the VRIO Framework. Binus Business Review, 2(2), 627. https://doi.org/10.21512/bbr.v2i2.1457.

[13] Manurung, H., Harjono, H., \& Sitorus, B. (2017). Analysis of Competitive Advantage Using Porter's Five Forces Approach in the Non-Formal Education Industry Environment in Pangkalpinang City. Jurnal Progresif Manajemen Bisnis, 20(2), 53-62. https://ejurnal.stie-ibek.ac.id/index.php/JIPMB/article/view/248.

[14] Guswandi, D., Sahara, \& Djohar, S. (2018). Strategic Factor Analysis for Construction Consultant Business in Indonesia. European Journal of Business and Management, 10(36), 57-62. https://doi.org/22222839

[15] Firmiyanti, R. D., Satria, A., \& Saptono, I. T. (2019). Developing Business Strategy for Local Television Network Into The Digital Broadcasting Competition in Indonesia: A JPM Case Study. Indonesian Journal of Business and Entrepreneurship, 5(2), 168-180. https://doi.org/10.17358/ijbe.5.2.168.

[16] Wongwa, R. S. (2016). Business Planning Entrepreneur Education Training Services "Smart Entrepreneur". Jurnal Bisnis Dan Manajemen, 52(1), 142-159.

[17] Saragih, J. T., \& Suwardi, E. (2015). Competitive Strategy PT. Perusahaan Gas Negara (Persero) Tbk SBU Distribution Region I. Jurnal Manajemen, Strategi Bisnis Dan Kewirausahaan, 8(2), 109120.

[18] Sukaatmadja, I. P. G., Nyoman, N., Yasa, K., \& Rahyuda, H. (2015) Traditional Market Development Strategy Based on Local Wisdom to Alleviate Poverty in Bali. Jurnal Manajemen, Strategi Bisnis Dan Kewirausahaan, 8(2), 121-129.

[19] Wiagustini, N. L. P. (2020). Intensive and Integrative Strategy: Strategy for Developing Small and Medium Industries of Herbal Products in Badung Regency. Matrik: Jurnal Manajemen, Strategi Bisnis Dan Kewirausahaan, 14(2), 283-293. https://doi.org/10.24843/MATRIK:JMBK.

[20] Mahfud, T., \& Mulyani, Y. (2017). QSPM Method Application QSPM Matrix. Jurnal Sosisal Humaniora Dan Pendidikan, 1(1), 6676.

[21] Hidayati, I. Y., Mukhammad, B., \& Akbar, B. (2019). Clinic Business Development Strategy Q Medical through Sustainable Development Goals Approach. Jurnal Riset Ekonomi Manajemen, 3(1), 1-10.

[22] Prasasti, A. K. (2020). Analysis of Competitive Advantage Based on Porter's Five Forces Method at Hotel Pelangi Malang. Jurnal Ilmiah Mahasiswa FEB Universitas Brawijaya, 21(1), 1-9.

[23] Wibawa, B. M., Rahmawati, Y., \& Rainaldo, M. (2018). Analysis of the Online Ride Sharing Service Business Industry in Indonesia. Esensi: Jurnal Bisnis Dan Manajemen, 8(1), 9-20. https://doi.org/10.15408/ess.v8i1.5739.

[24] Ruslim, F. A., \& Indriyani, R. (2015). Business Development Strategy of PT. ABC. Jurnal Agora, 3(2), 439-446.

[25] Hari, B., \& Rachmawati, D. (2011). Analysis of the Company's Strategy in Conducting Inter or Inter-Industry Mergers or Acquisitions. Jurnal Ilmiah Manajemen Bisnis, 11(1), 237-248.

[26] Jane, O. (2011). Analysis of Potential Partnerships as a Mode to Improve Innovation and Technology Capability. Jurnal Administrasi Bisnis Unpar, 7(2), 192-205. https://doi.org/10.26593/jab.v7i2.407.

[27] Maryanto, B. (2017). Big Data and Its Use in Various Sectors. Jurnal Media Informatika, 16(2), 14-19. https://jurnal.likmi.ac.id/Jurnal/7_2017/0717_02_BudiMaryanto.pdf. 